Articles

\title{
Map, Foundations, Recipe, Burden: Teachers' Conceptual Metaphors on Lesson Planning
} Mapa, base, receita, carga: metáforas conceituais sobre a planificação do ensino Mapa, base, receta, carga: metáforas conceptuales sobre la planificación de la enseñanza

\author{
Paola Alarcón ${ }^{1}$ - Claudio Díaz ${ }^{2}$ - Tania Tagle ${ }^{3}$ \\ Víctor Vásquez ${ }^{4}$ - María Jesús Inostroza ${ }^{5}$ \\ Marcela Quintana ${ }^{6}$ - Lucía Ramos ${ }^{7}$
}

1. Profesora Asociada, Departamento de Español. Universidad de Concepción. Concepción - Chile. https://orcid.org/0000-0001-7217-5668. E-mail: palarco@udec.cl.

2. Profesor Titular, Director Magíster en Innovación de la Enseñanza, Aprendizaje y Evaluación del Inglés, Departamento de Currículum e Instrucción. Facultad de Educación, Universidad de Concepción. Concepción - Chile. https://orcid.org/0000-0002-9024-2497. E-mail: claudiodiaz@udec.cl.

3. Profesora Asociada, Facultad de Educación. Universidad Católica de Temuco - Chile. https://orcid.org/0000-0002-0299-1827.E-mail: ttagle@uct.cl.

4. Profesor de Español, Estudiante de Magíster en Lingüística Aplicada. Facultad de Humanidades y Arte - Universidad de Concepción. Concepción - Chile. https://orcid. org/0000-0003-1334-9896. E-mail: vicvasquez@udec.cl.

5. Profesora Asistente. Jefa de Carrera de Pedagogía en Inglés. Departamento de Currículum e Instrucción. Facultad de Educación - Universidad de Concepción. Chile. https:// orcid.org/0000-0002-0037-2897. E-mail: minostrozaa@udec.cl

6. Profesora Asociada. Departamento de Educación y Humanidades - Universidad Arturo Prat. Chile. https://orcid.org/0000-0002-1649-6384. E-mail: maquinta@unap.cl.

7. Profesora Asistente. Departamento de Estudios Humanísticos. Facultad de Humanidades, Universidad Católica del Norte. Chile. https://orcid.org/0000-0001-8155-335X. E-mail: luramos@ucn.cl.

(cc) BY

This content is licensed under a Creative Commons Attribution License, which permits unrestricted use and distribution, provided the original author and source are credited.

D.E.L.T.A., 35-4, 2019 (1-22): e2019350408 
ABSTRACT

Conceptual metaphor constitutes both the theoretical framework and a tool for eliciting and analyzing data in this qualitative research study. The aim of this study is to analyze the role of conceptual metaphors for unpacking research participants' conceptualizations about lesson planning in Chilean schools. An eliciting metaphor questionnaire was designed to require respondents to complete the statement "lesson planning is like...because...". The data were analyzed through content analysis for metaphors, as follows: pre-analysis, labeling, classification, categorizing, peer judgment. The questionnaire was applied to 54 Chilean teachers from different schools. Four metaphor categories were obtained: Map, Foundations, Instructions, Burden.

Keywords: qualitative research; teacher beliefs; discourse analysis; conceptual metaphors.

\section{RESUMO}

A metáfora conceitual constitui o quadro teórico e, ao mesmo tempo, a ferramenta de elicitação e análise desta investigação do tipo qualitativo. O objetivo deste estudo é analisar o papel das metáforas conceituais para revelar as conceptualizações dos participantes da investigação sobre a planificação das lições nas escolas chilenas. Elaborou-se um Questionário de Elicitação de Metáforas (CEM), no qual se pede para completar o enunciado "a planificação do ensino é como... porque...". Os resultados foram analisados mediante uma análise de conteúdo para a metáfora, o qual compreende as etapas: pré-análise, etiquetado, classificação, categorização, juizo de pares. O questionário foi aplicado a 54 docentes de diferentes estabelecimentos educacionais chilenos. Foram obtidas 4 categorias de metáforas: Mapa, Cimento, Instrutivo, Carga.

Palavras-chave: metáfora conceitual; profesores; planificação do ensino; análise de conteúdo.

\section{RESUMEN}

La metáfora conceptual constituye el marco teórico y, a la vez, la herramienta de elicitación y análisis de esta investigación de tipo cualitativo. El objetivo de este estudio es analizar las creencias de docentes chilenos con respecto a la planificación de la enseñanza. Se 
elaboró un Cuestionario de Elicitación de Metáforas (CEM), en el que se pide completar el enunciado "la planificación de la enseñanza es como ... porque...". Los resultados se analizaron mediante un análisis de contenido para la metáfora, el cual comprende las etapas: (1) preanálisis, (2) etiquetado, (3) clasificación, (4) categorización, (5) juicio de pares. El cuestionario se aplicó a 54 docentes de diferentes establecimientos educacionales chilenos. Se obtuvieron $\mathbf{4}$ categorías de metáforas: Mapa, Cimiento, Instructivo, Carga.

Palabras clave: metáfora conceptual; profesores; planificación de la enseñanza; análisis de contenido.

\section{Introduction}

This article presents the results of an investigation that analyzed teachers' beliefs about a particular aspect of their professional work: lesson planning.

As stated by Reddy (1979) and Lakoff and Johnson (1980), metaphors are an essential part of our conceptual system and play a role not only in our language, but also in reasoning and attitudes. From these seminal studies, this approach has developed outstandingly, which has led to investigations that apply the conceptual metaphors to several domains (For an overview of the applications, see Gibbs 2008; Landau, Robinson \& Meier 2014). As explained in this article theoretical framework, metaphor has been applied as a tool for eliciting and analyzing teachers' beliefs.

In Chile, the Ministry of Education (MINEDUC) sets minimum learning outcomes and contents that have to be covered gradually and sequentially throughout the different levels of education. These learning outcomes are the first level of curriculum implementation, as defined by the guidelines provided by the State to lead teachers on the teaching, learning, and assessing process that should take place in the classroom. These guidelines are the initial tools available for teachers so that they can manage and contextualize the curriculum in terms of the social reality in which they teach (CPEIP 2010). Through this initial action, the teacher must display a range of knowledge, skills and strategies that evidence their roles as professional educators; and which allows them to turn an original disciplinary knowledge into knowledge that 
Paola Alarcón, Claudio Díaz, Tania Tagle, Víctor Vásquez, María Jesús Inostroza,

Marcela Quintana, Lucía Ramos

can be taught and learned by their students. Teachers, in essence, should be an active participant in the process of lesson planning. However, in recent years, lesson planning has been disputed in Chile, since, as some teachers think, it has become a demanding and cumbersome task that contributes to working overload. In view of the significance of this aspect for teaching, this investigation is aimed at analyzing the role of conceptual metaphors for unpacking research participants' conceptualizations about lesson planning in Chilean school.

In the theoretical framework, the main features of the conceptual metaphor are described as well as its contribution to education, from the linguistics field. Then the methodology by means of which this investigation was conducted is presented, followed by the analysis of the results and conclusions.

\section{Theoretical Framework}

\subsection{Conceptual Metaphor}

Conceptual metaphors allow examining teacher cognition, which is understood as "the observable dimension of teaching - what teachers know, believe, and think" (Borg 2003: 81). It is assumed that in order to improve teachers' professional performance it is essential to understand the structure of their beliefs (Freeman 2002: 3).

Conceptual Metaphor Theory is one of the main research areas in Cognitive Linguistics, which defines language as an instrument to organize knowledge (Geeraerts \& Cuyckens 2007; Ibarretxe-Antuñano \& Valenzuela 2012; Dabrowska \& Divjak 2015). Consequently, language investigation allows access to the conceptualization patterns in speakers (Evans \& Green 2006).

In the Cognitive Linguistic view, "when one conceptual domain is understood in terms of another conceptual domain, we have a conceptual metaphor. This understanding is achieved by seeing a set of systematic correspondences, or mappings, between the two domains" (Kövecses 2010: 324). 
The conceptual metaphor is a projection of elements, properties, and inferential principles from a more concrete domain (SOURCE DOMAIN) to a more abstract domain (TARGET DOMAIN) (Kövecses 2010; Landau et al. 2014). This set of correspondences between both domains defines the conceptual feature of the metaphor, as established by Lakoff and Johnson in their work Metaphors we live by (1980). These authors remarked that the metaphor not only manifests itself in the language level, but also in reasoning. For example, given knowledge about journeys, people know that at least it involves travellers, routes and destination, and that they are several types of journeys; similarly, it can be inferred what will happen if the travellers find obstacles. At the same time, people know about personal relationships. Thus, an expression referring to love relationships as "we could not overcome obstacles, so that each of us took their own ways" accounts for the correspondence between obstacle (source domain JOURNEYs) and relationship troubles (target domain PERSONAL RELATIONSHIPS), according to the conceptual metaphor PERSONAL RELATIONSHIPS ARE JOURNEYS (the name of the metaphor is written with small caps). Other equivalences between both domains are: People are travellers; to start another relationship is taking another way, etc.

Within this framework, it is argued that metaphors permeate daily discourse, unconsciously and automatically, unlike the traditional view, which considers it as a rhetoric and literary device.

In education, conceptual metaphor is a valuable tool for understanding the beliefs of the participants of the education process, regarding topics such as the teacher's role, teaching, learning and students. Research has enquired the professional identity of pre- and in-service teachers (Oxford et al. 1998; De Guerrero \& Villamil 2002; Saban 2004, 2006, 2010; Saban, Kocbeker \& Saban 2007); the evolution of these beliefs according to years of work experience (Thomas \& Beauchamp 2011); the impact of contextual factors on the construction of their professional identity (Ben-Peretz, Mendelson\& Kron 2003; Leavy, McSorley \& Boté 2007). Along with these, other topics have been addressed, such as the use of applied technology in teaching (Bağc1\& Coklar 2010); critical thinking in academic writing (Wan, 2015); teaching materials and evaluation (Eren \& Tekinarslan 2013). 


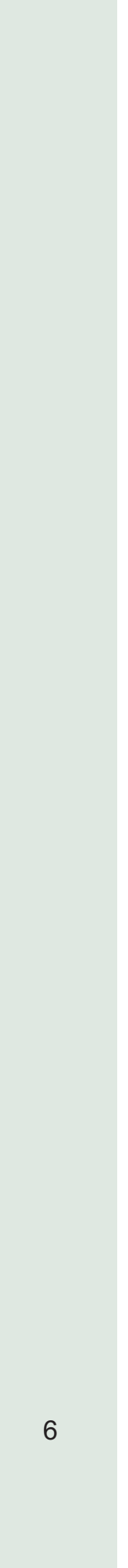

Paola Alarcón, Claudio Díaz, Tania Tagle, Víctor Vásquez, María Jesús Inostroza,

Marcela Quintana, Lucía Ramos

Metaphor facilitates reflection and can promote teachers' professional development since it makes explicit their implicit beliefs (Marshall 1990; Tobin 1990; Oxford et al. 1998; Sykes 2011; Seung, Park \& Jung 2015). According to Saban (2010), metaphor construction can be a liberating experience for teachers, as it helps them to understand the professional circumstances in which they are involved. Tobin (1990) indicates that even when teachers decide to change their approach to teaching, metaphor can promote this change by facilitating the analysis and reflection on their role and performance. Sykes (2011) highlights the use of metaphor as a means to facilitate reflection on the teaching field. Following Marshall (1990), the author maintains that "the process of reflecting on the roles of teachers and learners has been found to broaden the perspectives of what teaching entails and help to reconceptualize problematic situations in student teachers" (Sykes 2011: 10).

This study employs the concept of elicited explicit metaphor, coined by Low:

By 'elicited' metaphor, I mean that the respondent is prompted (linguistically or visually) by a researcher to produce a metaphorical expression or proposition. The respondent is generally made aware that she is being prompted (with words like "metaphor", "analogy" or "comparison" commonly being used), but it is possible that the prompt is not recognised as such. (2015: 17)

A commonly used instrument for eliciting metaphors is the written prompt, by means of a fill-in-the-blank form, that expresses the target domain and the participant has to provide a term for the source domain. In the current study, participants are requested to fill in the following statement "In Chilean society, the teacher, as an educational professional is like....because...". The product is an explicit metaphor, a kind of linguistic metaphor where the source domain term is given by the participant, without the need for the researcher to infer it.

According to Low (2015: 26), when participants have provided a form such as "A is like B", it is generally assumed that the linguistic statement can be converted into a conceptual metaphor, without any problem. However, the completion of the linguistic formula does not 
ensure that the researcher codes the results as a conceptual metaphor. The researcher should approach the response as a discourse point and should examine the argumentation that follows after "because" (Strugielska 2015), to configurate the target domain, establishing conceptual correspondences between both domains, which allows researchers to postulate the respective conceptual metaphors.

\subsection{Lesson Planning}

Lesson planning is a type of organization which unifies and structures the teaching and learning process. It considers the student, the context, the means and available materials, in order to reach the posed learning objectives. The lesson planning process is aimed at students with specific personal and academic characteristics, who are immersed in a familiar, social and cultural environment; therefore, an analysis and a careful decision-making process are needed by the teacher.

In the Chilean context, the MINEDUC (2015) indicates that "lesson planning means to put into practice the pedagogical knowledge. When planning, the following questions should be kept in mind: What should my students learn?, Which activities will help them to learn this the best way?, How long do they need in order to learn it?, What spaces are the most adequate for them to learn?, What resources will facilitate learning?, How can I collect evidence of learning?, How can they show what they learned?, among others". The teaching process is intrinsically related to how this process is designed, organized and taken to practice through lesson planning.

Hagen (2008: 27) defines lesson planning as a "group of activities that are combined, explained and developed in accordance with an objective, which determines what the students will achieve at the end of the lesson". This objective makes explicit what the students will achieve. Regardless of the specific content that is to be taught, lesson planning must be articulated with the didactic triangle, made by the student, the content and the teacher (Lewis \& Hurd 2011).

The taught content should be contextualized in a learning environment that promotes aspects such as motivation, learning and the students' capacity to organize their own mental structures. In addition, 
the content must be relevant and practical in order to strengthen students' skills (Kilic 2010).

The selected activities must be coherent with the aimed objective. Thus, it creates a stable platform with a good learning and teaching environment centered on the student, allowing his or her learning abilities to be developed and strengthened.

In regards to the individual differences, it is necessary to mention that it is crucial to understand the students' characteristics in order to determine the competences that need to be developed.

In short, lesson planning is considered a fundamental pedagogical tool to contextualize the teaching and learning process and to situate the student in the center of this process (Brown 2008).

As presented, lesson planning is an essential part of the teaching and learning process, and teachers must have the competences to design it. Together with this, however, in this study it is argued that it is also necessary that teachers value the importance of lesson planning and have positive beliefs about this part of their professional performance, which was researched through conceptual metaphor.

\section{Method}

This qualitative investigation has a phenomenological design, since it focuses on the individual experiences of the participants. In other words, the phenomena are aimed to be understood and characterized from the point of view of the subjects (Creswell 2007). This design allows analyzing the meanings of lesson planning arising from the interpretation of the teachers through conceptual metaphor. In qualitative research as it is the case of this study the size of the sample is not at stake since the main aim of qualitative studies is not to generalize the findings or conduct high level statistical analyses, but to gain a deep understanding of the phenomenon that is being analyzed. This investigation focuses its attention on the participants' beliefs about lesson planning. Therefore, lesson planning is the core category in this study and is defined as the teachers' action of organizing the teaching and learning process to engage and motivate students to learn. 


\subsection{Subjects}

The instrument was applied to 54 in-service teachers from different Chilean schools. Female teachers comprise $67 \%$ of the sample, while $33 \%$ are male. $35 \%$ are aged 29 or younger; $65 \%$ are 30 years old or more. Regarding to the type of school where they work, $49 \%$ of the teachers work in private schools with State subsidy, $29 \%$ in schools funded by the State and $22 \%$ in private schools. The participants of this study represent a convenient and intentional sample, commonly used in qualitative studies, it is of course a non-experimental research sample.

\subsection{Data Collection Instrument}

A Questionnaire for Metaphor Elicitation (CEM, in Spanish) was designed according to previous works that used conceptual metaphor to elicit beliefs in the field of education (Nikitina \& Furuoka 2008; Kasoutas \& Malamitsa 2009; Eren \& Tekinarslan 2013). The instrument has three parts. In the first part, the sociodemographic and professional details are requested, in order to establish correlations with the metaphor categories. In the second part, conceptual metaphor is explained and examples of well-constructed metaphors are developed, that is to say, where there are two conceptual domains, and it is possible to identify correspondences between them. Similarly, they are given examples where there are not metaphors, but literal descriptions of a concept. In the third part, the subjects have to complete the statement: "teaching planning is like... because...".

\subsection{Analysis Procedure}

The analysis is based on Moser (2000), Saban et al. (2007), and Saban (2010), who dealt with content analysis for conceptual metaphors, which consists of the following stages: (1) pre-analysis, (2) labeling, (3) classification (clarifying and deleting), (4) categorizing, (5) peer judgment. 
Paola Alarcón, Claudio Díaz, Tania Tagle, Víctor Vásquez, María Jesús Inostroza,

Marcela Quintana, Lucía Ramos

The pre-analysis determines the specific stages in which the data will be examined and organized. Labeling consists of collecting all the answers and codifying the source domain (for example: COMPASs, COLUMN).

During the classification, the data are revised and the conceptual metaphor components are identified: target domain, source domain and correspondences. In this study, target domain is LESSON PLANNING. The source domain is provided by the participants in their answers. The correspondences are the relations between both domains, as can be extracted by the justification of the chosen source domain. Following the proposal of Pragglejaz Group (2007), in this stage, a contrast is established between the basic or concrete meaning (in the source domain) and the contextual meaning, that is, what lesson planning means in the educational field. From this, the elements necessary to establish the prevailing characteristics of each metaphor are obtained, which allow the categorization later on. In addition, any answer that is not a metaphor is discarded, for example literal descriptions (such as "lesson planning is a procedure that we teachers carry out to organize our lessons") or confusing answers, in which a source domain cannot be clearly identified.

During the categorization stage, the semantic criterion of meaning similarity is applied to group the metaphors, both by similarity of the source domain as by the features with which the lesson planning is characterized. In this way, the categories obtained are a group of metaphors which share attributes about the lesson planning.

The peer judgment stage is aimed at reinforcing the reliability of the categorizations. For this, the analyses are contrasted in groups as previously carried out by each of the researchers. The unclear cases are aimed to be resolved and the maximum agreement achieved in the categorization.

\subsection{Instrument Application}

The research team contacted school principals to explain the study objectives and to obtain their authorization. Once obtained, the research team sent a letter of consent to the teachers who decided to participate, 
in which they were informed about the project and data confidentiality. Later, the questionnaire was applied at the time and place as agreed on with each teacher.

\section{Results and Discussion}

Through content analysis, 4 categories were identified for the metaphor: Map, Foundations, Instructions, Burden. It should be noted that the names of the category are labels that represent the properties assigned to lesson planning. Table 1 presents the categories together with their respective conceptual metaphors.

Table 1 - Categories and conceptual metaphors about teaching planning

\begin{tabular}{|c|c|}
\hline Categories & Metaphors \\
\hline Map & $\begin{array}{c}\text { Map (6), Compass (6), Road (3), Navigation Chart (2), Roadmap } \\
\text { (2), Guide (2), Travel itinerary, Lighthouse (1), Helm (1), } \\
\text { Railroad lines, Step }\end{array}$ \\
\hline Foundation & Foundation (3), Column, Bridge \\
\hline Instructions & $\begin{array}{l}\text { Cooking recipe (3), Menu, Guideline, Book table of contents, } \\
\text { Cooking, Instruction for assembling furniture }\end{array}$ \\
\hline Burden & $\begin{array}{c}\text { Car, Stone, Traffic light button, Cleaning the top of a fridge, The } \\
\text { ten commandments, Fridge magnet, Piece of furniture, Support } \\
\text { but also a burden, A pain, Torture, Meaningless sacred rite, } \\
\text { Christmas tree, A stone in your shoe, a Check, A never ending } \\
\text { story }\end{array}$ \\
\hline
\end{tabular}

In some categories, the metaphors about lesson planning will be described in the framework of the conceptual metaphor about the teaching and learning process, of which lesson planning is a component.

\subsection{Lesson Planning Is the Map of a Journey}

According to this category, the teaching and learning process is conceptualized as a journey, which goal is achieving learning. Students 
are travellers guided by the teacher, who must know the route to follow. It is in this point where planning shows its utility and importance, since it implies that this journey has been prepared with accuracy, according to the goal to be achieved, as observed in the following sample of answers:

1. Lesson planning is a map, because it shows the road to achieve a determined place where we want to get. It is in this way that lesson planning shows us the steps needed to achieve the learning objectives. In most of the cases, a map shows more than one road to reach the specific student, so in that way lesson planning is also flexible as we can modify it according to the needs of the class, but always trying to reach our objective.

2. Lesson planning is a map for the route, in which everything that is needed to guarantee and promote students' learning is provided, and just like in the map it specifies everything that the teacher should consider to reach effective learning in the lesson.

3. Lesson planning is like a roadmap, because from what is proposed in it, a line can be followed to fulfill what the Ministry proposes as a goal to achieve for each student.

4. Lesson planning is like a compass, because just like a compass it is useful for travelling, in a fieldtrip to guide us and helps us not to get lost on the way. Many times, it is forgotten or discarded, but it's always necessary, since when we resort to it, it gives us the necessary help to resume our path.

5. Lesson planning is like a map or roadmap, because the lesson planning is followed, it is written to guide ourselves in the daily work to not be lost and improvising.

As can be noted, the guide should know the different routes that can be taken to reach the destination. In this way, the danger of taking a wrong way is avoided. In the target domain, teaching is conceived as a process that must be coherently projected according to the learning objectives, and which must avoid improvising. Table 2 shows the conceptual correspondences between the target domain of teaching and the source domain of travelling. 
Table 2 - Conceptual correspondences of the conceptual metaphor THE TEACHING AND LEARNING PROCESS IS A JOURNEY

\begin{tabular}{|c|c|}
\hline $\begin{array}{c}\text { Target domain } \\
\text { TEACHING AND LEARNING PROCESS }\end{array}$ & Source domain JourneY \\
\hline Teacher & Travel guide \\
\hline Students & Travellers \\
\hline Teacher / Ministry of Education & Entity issuing the map \\
\hline Achievement of the expected learning & Destination of the journey \\
\hline Lesson planning & Map \\
\hline
\end{tabular}

In short, lesson planning, according to this category, is the means (whether a map, compass, roadmap, etc.) which shows the way and helps the guide. It is important to point out, as evidence in these examples, two essential features of lesson planning related to intentionality and process flexibility. When designing the lesson planning, the teacher avoids teaching to be erratic and disorganized, and leads the objectives through activities, methodologies and pedagogical resources that facilitate learning. In turn, lesson planning should also account for flexibility principles that allow adaptation to the students' learning needs and to limitation given by the different socio-educational contexts.

\subsection{Lesson Planning Is the Building Foundation}

According to this category, the teaching and learning process is a building that must be precisely designed. Within this framework, lesson planning is the foundation of this structure. The following examples show the conceptual richness of the answers:

6. Lesson planning is like bridge suspenders, because it is the suspender that structures, strengthens, holds and guides the bridge so that the direction is the same and it doesn't fall.

7. Lesson planning is the foundation of a building, because the lesson planning is the basis of a lesson. That is to say, in a lesson planning, we as teachers must reflect on the most correct way to teach knowledge, considering the objectives, contents and students' context. 
The teaching and learning process is conceived as a building that requires basis and solid materials. Thus, a lesson that is carefully and coherently designed with well-established objectives is more likely to achieve students' learning. In this way, both coherence and rationality are two principles to which lesson planning must account for, as they allow the articulation of the different variables of the teaching and learning process in a logical way to achieve students' learning and their effective implementation in the classroom. Table 3 illustrates the conceptual correspondences to understand this concept of lesson planning.

Table 3 - Conceptual correspondences of the conceptual metaphor THE TEACHING AND LEARNING PROCESS IS A BUILDING

\begin{tabular}{|c|c|}
\hline Target domain & $\begin{array}{c}\text { Source domain } \\
\text { BuILDING }\end{array}$ \\
\hline TEACHING AND LEARNING PROCESS & Foundation builder \\
\hline Teacher & Users of the building \\
\hline Students & Foundation \\
\hline Lesson planning &
\end{tabular}

\subsection{Planning As Instructions}

The metaphors included in this category share the conceptualization of lesson planning as a set of instructions that the teachers must follow in order to achieve the learning objectives, as can be observed in the following answers.

8. Lesson planning is a well-done cooking recipe, because it considers many aspects and diverse factors before cooking the dish or carry out the lesson in the case of teachers. Lesson planning, like a cooking recipe, considers and selects the necessary ingredients (contents), materials (learning resources), and procedures (teachinglearning strategies). It also considers specific and necessary timing in order to perform each action. Lesson planning like a recipe requires a lot of dedication in its implementation, effort and vocation to fully achieve the proposed objective: a delicious and nutritious dish (an enjoyable and meaningful lesson). 
9. Lesson planning is a recipe; to be able to cook a delicious cake the main thing is to know the ingredients we need. Then, the cooking time for each of them, or what we need to mix. Ideally, we would have the tools to cook our meal without problems.

10. Lesson planning is like a menu, because it tells us what we should cook every day and give in the classroom.

The result of the teaching and learning process is constructed as a dish, which is prepared by following a set of instructions, within the metaphor framework of THE TEACHING AND LEARNING PROCESS IS COOKING. This dish is cooked for certain people: the students. Table 4 shows the metaphor correspondences.

Table 4 -Conceptual correspondences of the conceptual metaphor THE TEACHING AND LEARNING PROCESS IS COOKING

\begin{tabular}{|c|c|}
\hline $\begin{array}{c}\text { Target domain } \\
\text { TEACHING AND LEARNING PROCESS }\end{array}$ & $\begin{array}{c}\text { Source domain } \\
\text { Product }\end{array}$ \\
\hline Ministry of Education & Issuer of the recipe \\
\hline Teacher & Cook \\
\hline Students & People eating \\
\hline Lesson planning & Recipe \\
\hline
\end{tabular}

The answers show several degrees of participation or possibility of innovation of teachers. Teachers, as educational professionals, should be educated to become a reflective and critical subject of their surroundings, but also trained with a series of strategies and tools to allow the design, implementation and evaluation of teaching and achieve their students' learning. However, in their professional performance, they face different realities.

Each school establishes different procedures for lesson planning, with different opportunities for innovation. Thus, for example, answer (10) tells us that some schools deliver already prepared lesson planning that the teacher should only implement. The result of the pedagogical process will depend on how good the teacher follows the instructions, which will impact in their students' learning. Conversely, answers (8) and (9) provide a more degree of participation by the teachers, 
according to a process of reflection where they consider the objectives given by the Ministry. The association of lesson planning with a joyous process, such as cook a delicious meal shows a positive valuation of this process.

\subsection{Lesson Planning Is a Burden and Other Negative Metaphors}

Unlike the other categories, the category Burden included several metaphors chosen by the subject to characterize different negative features of lesson planning. Therefore, the correspondences were established between the characteristics and not between the elements of the involved conceptual domains.

The metaphors highlight that lesson planning is an imposition on the teacher's work, an unnecessary task, a hindrance to innovation, an annoyance, as shown below.

11. Lesson planning is a piece of furniture, because it does not have a major influence, more than a decoration, most of lesson planning end up piled up in the office of the academic director. Due to the teachers' overwhelming work load, lesson plans end up being a formality that takes time away from preparing quality material o spending time with the family.

12. Lesson planning is a pain, because it must be endured as a part of the requirements imposed to perform the noble work that we love.

13. Lesson planning is a check, because it must be completed or filled always in the same way, there is no room for innovation. It must be done in that way in order to receive the benefits from the employer (payment). If mistakes are made, there is no payment.

14. Lesson planning is like a Christmas tree, because lesson planning is a very well decorated instrument with beautiful figurines, corresponding to the text that is depicted there (lesson description), but that in the end is not the most important, and makes us waste time decorating it. What we do is to forget the nativity scene, which refers to the lesson creativity, to reinforce the development of skills in our 
students, that is the most important thing, decorating the lesson planning and wasting time is done just for the fulfilling the requirements

This negative characterization shows lesson planning as a burden task in teaching, which would even contribute to work overload. It is interesting to note how an activity which main aim is designing teaching before it is carried out turns into an action with a strong negative load, and that does not necessarily respond to the essential principles of flexibility and guidance that it possesses. This may not be directly related to the act of lesson planning itself, but more to the use it has been attributed in the different socio-educational contexts. It has become a mechanism of control, regulation and inspection of what the teacher does in the classroom, distorted from its clear function as a guide and help. In turn, some schools seem to have developed some strategies to evade the burden caused by lesson planning, which leads to the reproduction of mechanical, strict documents with no pedagogical value, which only satisfy the order given by a superior.

\section{Conclusions}

In this qualitative study, different categories about the concept of lesson planning were obtained from Chilean in-service teachers through the analysis of conceptual metaphors. The results allow us to assert that the conceptual metaphors reflect self-images, beliefs, emotions and assessments by means of which the individuals give sense, in general, to different aspects of their experience. In particular, the analysis shows how the subjects understand lesson planning.

Teachers fulfill a set of roles in the pedagogical process that go from the development of functions as observers to those related to assessment and reflection on teaching. In this sense, lesson planning is one more of the teacher's functions that are carried out before entering the classroom. It is a period of analysis, decision making, and teaching organization, in which the teacher anticipates, according to their perception, what is needed for learning to occur. In the answers provided by the subjects, it is observed that the categories Map, Foundations and Recipe (answers 8 and 9), apart from the specifications and differences, acknowledge the importance of this process and highlight that it should be safeguarded 
Paola Alarcón, Claudio Díaz, Tania Tagle, Víctor Vásquez, María Jesús Inostroza,

Marcela Quintana, Lucía Ramos

that learning is guided by clear objectives, which provide coherence to the activities, methodologies and teaching resources used.

Lesson planning is a great opportunity for continuous professional development, because it should respond to a logic of collaborative work between peers stimulating discussion and reflection on teaching, so that it does not become a mere verification requirement of what the teacher should do in the classroom, a situation that is reflected by the categories Burden, Instructions and Recipe (in answer 10). In addition, planning is a complex activity that implies the articulation of a set of important educational variables which operate in several education contexts, leading it to be flexible and dynamic. This study shows, however, that for some teachers, lesson planning is an imposition that has become a mechanical and meaningless process.

Given that beliefs change according to the years of teaching experience and other factors, and each educational center has their planning procedure, future studies will establish correlations between the categories and sociodemographic categories in order to further explain the obtained metaphors.

The investigations that use conceptual metaphors have been criticized for not explaining the analysis procedures and subjectivity when interpreting the results (Wan 2011; Seung et al. 2015; Low 2015). Therefore, the use of several analysis methods is a strategy that strengthens the validity of the results through the methodological triangulation. Consequently, and as it has been done in other investigation about teacher beliefs (Alarcón, Díaz \& Vergara 2015), in future studies about metaphors regarding teaching planning, different instruments for data collection will be applied, such as, focus groups or interviews, in order to deepen the analysis of the questionnaire answers.

Finally, it should be noted that the conceptual metaphor has been also used as an intervention strategy, particularly, as a tool for reflection to improve knowledge or the teaching practice (Seung et al. 2015). The development of each answer, where the subjects justify the election of the metaphor, shows that the conceptual metaphor motivated the reflection about this aspect in their professional performance. Consequently, once a vision about how teachers conceive and value lesson planning has been obtained, workshops can be carried out where these beliefs are critically discussed. 


\section{Funding Acknowledgements}

This work was supported by FONDECYT DE INICIACIÓN 11130482 "La metáfora conceptual como herramienta de análisis de creencias docentes en profesores de establecimientos educacionales de la comuna de Concepción"; and FONDECYT REGULAR 1150889 "Las dimensiones cognitivas, afectivas y sociales del proceso de planificación de aula y su relación con los desempeños pedagógicos en estudiantes de práctica profesional y profesores nóveles de pedagogía en inglés.

\section{References}

ALARCÓN, Paola; DÍAZ, Claudio; VERGARA, Jorge. 2015. Chilean preservice teachers' metaphors about the role of teachers as professionals. In: WAN, Wan; LOW, Graham (Eds.). Elicited Metaphor Analysis in Educational Discourse (p. 289-314). Amsterdam \& Philadelphia: John Benjamins Publishing Company.

BAĞCI, Hakki; ÇOKLAR, Ahmet Naci. 2010. Roles assigned by prospective teachers to themselves in terms of use of educational technology: A metaphor study. Procedia Social and Behavioral Sciences 2: 4412-4416.

BEN-PERETZ, Miriam; MENDELSON, Nili; KRON, Friedrich. 2003. How teachers in Different Educational Contexts View their Roles. Teaching and Teacher Education 19: 277-290.

BORG, Simon. 2003. Teacher cognition in language teaching: A review of research on what language teachers think, know, believe, and do. Language Teaching. The International Abstracting Journal for Language Teachers and Applied Linguists 36: 81-109.

BROWN, Julie. 2008. Student-centered instruction: Involving students in their own education. Music Educators Journal 94/5: 30-35.

CENTRO DE PERFECCIONAMIENTO, EXPERIMENTACIÓN E INVESTIGACIONES PEDAGÓGICAS (CPEIP). 2010. Carrera profesional docente. Un desafio para Chile. Santiago: Ministerio de Educación, Gobierno de Chile.

CRESWELL, John W. 2007. Qualitative inquiry and research design. Choosing among five approaches. London: Sage.

DABROWSKA, Ewa; DIVJAK, Dagmar (eds.). 2015. Handbook of Cognitive Linguistics. Berlin: De Gruyter Mouton. 
DE GUERRERO, Maria; VILLAMIL, Olga. 2002. Metaphorical Conceptualizations of ESL Teaching and Learning. Language Teaching Research 6/2: 95-120.

EREN, Altay; TEKINARSLAN, Erkan. 2013. Prospective Teachers' Metaphors: Teacher, Teaching, Learning, Instructional Material and Evaluation Concepts. International J. Soc. Sci. y Education 3/2: 435-445.

EVANS, Vyvyan; GREEN, Melanie. 2006. Cognitive Linguistics. An Introduction. Edinburgh: Edinburgh University Press Ltd.

FREEMAN, Donald. 2002. The hidden side of the work: Teacher knowledge and learning to teach. A perspective from North American educational research on teacher education in English language teaching. Language Teaching. The International Abstracting Journal for Language Teachers and Applied Linguists 35: 1-13.

GEERAERTS, Dirk; CUYCKENS, Hubert. 2007. Introducing Cognitive Linguistics. In: GEERAERTS, Dirk; CUYCKENS, Hubert. (Eds.). The Oxford Handbook of Cognitive Linguistics (pp. 3-21). Oxford: Oxford University Press.

GIBBS, Raymond. 2008. Metaphor and Thought. The State of the Art. In: GIBBS, Raymond (ed.). The Cambridge Handbook of Metaphor and Thought (pp. 3-13). Cambridge: Cambridge University Press.

IBARRETXE-ANTUÑANO, Iraide; VALENZUELA, Javier. 2012. Lingüística Cognitiva: Origen, principios y tendencias. In: IBARRETXE-ANTUÑANO, Iraide; VALENZUELA, Javier (eds.). Lingüistica Cognitiva (p. 13-38). Barcelona: Anthropos.

KASOUTAS, Michael; MALAMITSA, Katerina. 2009. Exploring Greek teachers' beliefs using metaphors. Australian Journal of Teacher Education 34/2: 64-83.

KILIC, Abdurrahman. 2010. Learner-centered micro teaching in teacher education. International Journal of Instruction 3/1: 77-100.

HAGEN, Kirk. 2008. Second language acquisition: An evolutionary linguistic approach. Michigan: University of Michigan Press.

KÖVECSES, Zoltán. 2010. Metaphor: A practical introduction, 2da. ed. Oxford/New York: Oxford University Press.

LAKOFF, George; JOHNSON, Mark. 1980. Metaphors we live by. Chicago: University of Chicago Press.

LANDAU, Mark; ROBINSON, Michael; MEIER, Brian (eds.). 2014. The power of metaphor: Examining its influence on social life. Washington, DC: American Psychological Association.

LEAVY, Aisling; MCSORLEY, Fiona; BOTÉ, Lisa. 2007. An examination of what metaphor construction reveals about the evolution of 
preservice teachers' beliefs about teaching and learning. Teaching and Teacher Education 23/7: 1217-1233.

LEWIS, Catherine; HURD, Jacqueline. 2011. Lesson study step by step: How teacher learning communities improve instruction. New York: Library of Congress Cataloguing-in-Publication Data.

LOW, Graham. 2015. A practical validation model for researching elicited metaphor. WAN, Wan; LOW, Graham (eds.). Elicited Metaphor Analysis in Educational Discourse (p. 15-37). Amsterdam: John Benjamins.

MARSHALL, Hermine. 1990. Metaphor as an instructional tool in encouraging student teacher reflection. Theory into Practice 29/2: 128-132.

MINISTERIO DE EDUCACIÓN DE CHILE (MINEDUC). 2015. Orientaciones técnicas para la planificación de aula. Para establecimientos en proceso de recuperación de clases. Retrieved from http://portales.mineduc.cl/usuarios/mineduc/File/2015/julio/ Orientaciones\%20Planificacion\%20Nacional.pdf.

MOSER, Karin. 2000. Metaphor analysis in psychology: method, theory, and fields of application. Forum: Qualitative Social Research 1/2. Retrieved from http://www.qualitative-research.net/fqs-texte/2-00/200moser-e.htm

NIKITINA, Larisa; FURUOKA, Fumitaka. 2008. A language teacher is like...: Examining Malaysian students' perceptions of language teachers through metaphor analysis. Electronic Journal of Foreign Language Teaching 5/2: 192-205.

OXFORD, Rebecca; TOMLINSON, Stephen; BARCELOS, Ana; HARRINGTON, Cassandra; LAVINE, Roberta Z.; SALEH, Amany; LONGHINI, Ana. 1998. Clashing metaphors about classroom teachers: Toward a systematic typology for the language teaching field". System 26/1: 3-50.

PRAGGLEJAZ GROUP. 2007. MIP: A method for identifying metaphorically used words in discourse. Metaphor and Symbol 22/1: $1-39$.

REDDY, Michael. 1979. The conduit metaphor. A case of frame conflict in our language about language. In: ORTONY, andrew. (Ed.), Metaphor and thought (p. 284-324). Cambridge: Cambridge University Press.

SABAN, Ahmet. 2004. Prospective classroom teachers' metaphorical images of selves and comparing them to those they have of their elementary and cooperating teachers. International Journal of Educational Development 24: 617-635. 


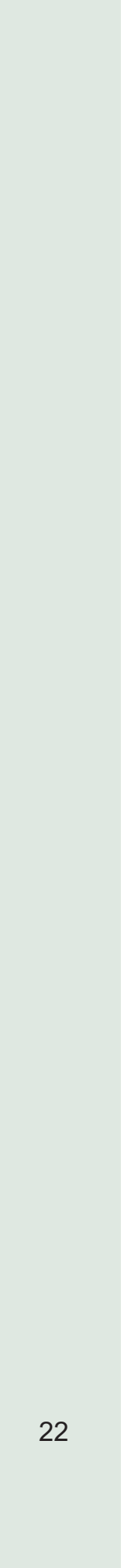

Paola Alarcón, Claudio Díaz, Tania Tagle, Víctor Vásquez, María Jesús Inostroza,

Marcela Quintana, Lucía Ramos

.2006. Functions of Metaphor in Teaching and Teacher Education: A review essay. Teaching Education 17/4: 299-315.

.2010. Prospective Teachers' Metaphorical Conceptualizations of Learner. Teaching and Teacher Education 26: 290-305.

SABAN, Ahmet; KOCBEKER, Beyhan; SABAN, Aslihan. 2007. Prospective teachers' conceptions of teaching and learning revealed through metaphor analysis. Learning and Instruction 17: 123-139.

SEUNG, Eulsun; PARK, Soonhye; JUNG, Jinhong. 2015. Methodological approaches and strategies for elicited metaphor-based research: A critical review. In: WAN, Wan; LOW, Graham. (Eds.). Elicited Metaphor Analysis in Educational Discourse (p. 39-64). Ámsterdam: John Benjamins.

STRUGIELSKA, Ariadna. 2015. A hybrid methodology of linguistic metaphor identification in elicited data and its conceptual implications. WAN, Wan; LOW, Graham (eds.). Elicited Metaphor Analysis in Educational Discourse (p. 65-92). Ámsterdam: John Benjamins.

SYKES, Joe. 2011. Facilitating reflection on implicit learner beliefs through metaphor elicitation. Journal of Pan-Pacific Association of Applied Linguistics 15/1: 91-113.

THOMAS, Lynn; BEAUCHAMP, Catherine. 2011. Understanding New Teachers' Professional Identities through Metaphor. Teaching and Teacher Education 27/4: 762-769.

TOBIN, Kenneth. 1990. Changing Metaphors and Beliefs: A Master Switch for Teaching? Theory into Practice 29/2: 122-127.

WAN, Wan. 2011. An examination of the validity of metaphor analysis studies: Problems with metaphor elicitation techniques. Metaphor and the Social World 1/2: 262-288.

.2015. Developing critical thinking in academic writing through a metaphor elicitation technique. An exploratory study. In: WAN, Wan; LOW, Graham (eds.). Elicited Metaphor Analysis in Educational Discourse (p. 213-237). Amsterdam: John Benjamins.

Recebido em: 02/07/2018

Aprovado em: 04/12/2018 